\title{
Networking Cooperation in Forming Soft Skills of a New Type of Teacher
}

Fayruza G. Rebrina, ${ }^{+*}$ Sabina D. Khakimova, ${ }^{\dagger}$ and Ann R. Ishkinyaeva ${ }^{+}$

\section{Abstract}

The primary aim of this research is to develop an effective network interaction model in developing a new teacher's soft skills. The authors carried out an analysis of a new teacher's necessary soft skills and the existing models of partnerships. They outlined their views on the development of a networking model that is aimed at the systematic formation of a teacher's soft skills. The empirical part is executed based on the Elabuga Institute of the Kazan Federal University. The created model can be used for the organisation of training system of a new type of teacher. It might as well be used as a model of the school-university partnership for revealing pedagogically gifted children or as an integrated model for the formation of basic teachers' soft skills in the university.

Keywords: Networking; Networking Cooperation Models; Soft Skills; New-Type Teacher; Outcomes; Formal and Non-Formal Education System.

\footnotetext{
${ }^{\dagger}$ Kazan Federal University, Russian Federation,

* Corresponding Author, Email: rfairuza@yahoo.com

(C) 2019 Rebrina et al. This is an Open Access article distributed under the terms of the Creative Commons Attribution License (http://creativecommons.org/licenses/by/2.0), which permits unrestricted use, distribution, and reproduction in any medium, provided the original work is properly cited.
} 


\section{Introduction}

The increased demand for highly skilled workforce compels the states to generate a higher return from education that would comply with international standards (Jonas et al., 2014). World trends in education are cantered on strengthening transnational integration, which allows accelerating the experience and technologies exchange (APEC Education Cooperation Strategies, 2016).

The globalisation of education, which is a process of cultural and conceptual unification of knowledge around the world, has created the possibility of equal access to the quality of knowledge regardless of location, income, race, gender and age. The growth of population mobility, IT penetration and a desire of higher education institutions to generate additional profit have led to the emergence of transnational education (Code of Good Practice in the Provision of Transnational Services, 2002; Vincent-Lankran, 2010). This process entails an increase in the value of additional skills (soft skills) acquired during training, as professional knowledge becomes standardised.

A student can learn without leaving the country within the framework of a franchise education programme or the networking cooperation between higher education institutions (Kamyshanchenko \& Stepanenko, 2014; Khabiri \& Bahabad, 2019; Shurygin \& Sabirova, 2017). Partnership development in the field of education is becoming more and more popular. The state cooperates with private educational organisations to provide population with quality education (Malik, 2010). The state position, regarding the sustainable development of education as an industry, allows creating the most effective teaching tools in the modern multicultural environment of students and teachers (Zhukova et al., 2019).

The following teacher's abilities become the most demanded abilities in society. These include effective interaction with students; motivating them to learn, gain the latest information, set the learning goals based on target outcomes as well as make an adequate choice. The teacher has new roles to play in the modern educational space, such as the producer of talented youth (Freeman, 2015), learning process designer, mentor in drawing an individual learning trajectory (Maharoff \& Hassan, 2015; Gerstein, 2017) and a social buffer for people with disabilities (Rouse, 2008). This is of course unlike the "Black hat" thinking ${ }^{1}$ (Al Jarrah, 2019) the teacher is hugely critical and avoids mistakes and risks in every way. This thinking is typical of the old, traditional, ineffective approach to communication with students. At this point, the teacher must have soft skills, be creative, generate ideas and effectively manage the team.

The research problem is that future teachers are taught in a way to form professional skills based on subject theory and classical teaching methods. Any curriculum, on the one hand, should continue to form practical professional skills, and on the other, create knowledge and experience of cooperation and joint work in working areas.

This research suggest in preparing a new type of teacher and developing his/her soft skills using the advantages of networking cooperation.

To accomplish the objectives, this research is organised into six sections. The literature review is dedicated to the issues of new-type teachers' soft skills and networking cooperation in education. The methodological basis of the proposed model of networking cooperation is discussed in the methods section. The problems of realisation of networking cooperation between the links of formal and non-formal education both in local and international perspective are critically analysed in the results and discussion section.

\section{Literature Review}

Soft skills are unified skills that represent a wide range of competences, behaviour, attitudes and

\footnotetext{
1"Black hat" - individuals looking for pitfalls to avoid mistakes and risks.
} 
personal qualities that allow people to effectively interact with each other, perform well and achieve goals. The ability to understand and identify one's own and other people's emotions and the ability to control them is emotional intelligence (EQ). As a societydependent quality, EQ is susceptible to development, consistently passing through the following stages: perception, understanding and regulation of emotions (Joseph \& Newman, 2010).

Modern social intelligence studies multidimensionality and connection with academic intelligence giving the leading role to the cognitive component (Kang et al., 2006). Social intellect is considered as an integrative individual's ability to recognise verbal and nonverbal human reactions, feelings and emotional states, to understand and predict own and other person's behaviour in different circumstances (Mikhailova, 2007). Scientists fill the structure of social intelligence with different components. The social intelligence effect on communication and the ability to use it are covered by the professional teachers' competence.

The process of allocating soft skills that a newtype teacher should possess is complicated by the fact that the teachers' basic soft skills develop into professional ones, thereby moving to hard skills (Galazhinsky, 2017).

Soft skills are formed for a long time, but their dynamic development is subject to both diagnosis and self-diagnosis (Claxton et al., 2016). Soft skills might be observed and trained by engaging students in self-reflection, selfanalysis and into the process of realising the learning strategies.

Networking in education is viewed from the standpoint of organisational forms, outcomes reaching, goal setting and cooperation management. The goals of networking cooperation are the following: gaining advantages from integrating the unique experience, knowledge, capabilities and resources of network participants, and/or obtaining an effective method for implementing education programmes. Networking participants can reach outcomes by integrating their resources (Popova, 2016).

This research suggest that soft skills are essential for education quality, only if the latter are formed in the context of partnership relations between formal and non-formal educational establishments, based on the practice-oriented principles and activity-based approach.

Thus, the purpose of this research is to build an effective model for networking cooperation that will contribute to new-type teachers' soft skills formation.

\section{Methods}

The research was conducted under the collaboration between two faculties (Biology and Chemistry, Economics of enterprises and organisations) in 2016-2017 in the Elabuga Institute of Kazan Federal University (Russia). The collaboration goal was to build a model of networking cooperation that shall contribute to new-type teacher's soft skills formation. The introduced model is an original view on solving the problem of preparing a teacher for Education 3.0 (a mixtire of cognitive psychology and active use of web-based technologies).

The conceptual research basis is in the following. The ideas of the priority of result (Kasprzhak \& Kalashnikov, 2014) at each stage of soft skills formation are outlined in the model. To attain the objectives of the research, the modular approach (Pachauri \& Yadav, 2014) to soft skills formation in the university, as well as the systematic formation of soft skills, were applied. Based on the original vision of the multi-level structure of teacher's soft skills, their successive formation was modelled from the initial to the advanced level.

The introduced model of networking cooperation implies three stages of activity. At the first stage, vocational guidance work is organised with the 12-16-years-old secondary school students to identify the pedagogically gifted children that shall be included in the personalised soft skills formation programme. Academic training integration with the personalised development plan, designed with 
some elements of profession-oriented instruction (mentoring, social projects, workshops, etc.) brings up a school education programme that shall meet the activity-based and practice-oriented approaches.

At the second stage, one of the three soft skills formation models is applied. At the third stage, the young teacher undergoes a yearlong internship at the educational establishment under the guidance of an experienced mentor. The stage contents are described in the results.

There were prototypes done for some part of the first stage, outlined in the introduced model, within the framework of partnership relations between the university, the Autonomy NonProfit Organisation "Kazan Open University of Talents 2.0" (defines some common concerns for employers that become significant barriers to the talent acquisition), social volunteer organisations and secondary schools of Elabuga. In particular, this research has designed and tested a prototype of a vocational-oriented school for the 14-17-years-old secondary school students. The school is an intensive six-day course of immersion into the atmosphere of vocational tests, workshops, research and social projects, moderation, business games and other forms of intense soft skills formation. Prototyping has imposed a goal to gain experience in building a model of networking cooperation as an accelerator of soft skills formation. Such a prototype can also be applied to identify the pedagogical giftedness and professional self-determination of schoolchildren.

The students were chosen using motivation skills, associated with their readiness to develop professional competencies. Their number depended on the number of groups and their representation. One student-mentor manages the group of 5-6 people.

In the specified period, 95 schoolchildren aged 14-17 (8-10 grades), 17 students (bachelors in
Education) and three experienced mentors (school and university teachers) took part in school activity. The number of full-time students limits sampling.

The prototype application turned out to be a problem due to a lack of tools that would allow determining real changes in the structure of social and emotional intelligence competencies being formed. The researchers could make assumptions on the soft skills formation dynamics only based on indirect data from observing changes in the quality and nature of mentor-student-to-student interaction. However, since such an assessment is subjective, the researchers failed to bring forward the observed results. The research errors were taken into account and shall be corrected in a second prototype. In particular, the researchers have to build a model for competency dynamics based on the model of disparity between personal competencies and expected ones, and to introduce factor analysis (Di Russo, 2016).

The prototype testing confirmed that pedagogically gifted children should be allocated to teaching orientation class.

\section{Results}

There is formal, non-formal and informal education. Each form is specific when it comes to acquiring knowledge and life experience; these are environments for personality development. These forms might be used to build a model of networking cooperation contributing to a newtype teacher's soft skills formation (Figure 1).

Networking cooperation in formal and nonformal education has broader opportunities for forming socially important skills through education. Hence, through collaboration with partners, the problems might be solved by preparing children for life in society as well as preparing the teaching staff. 


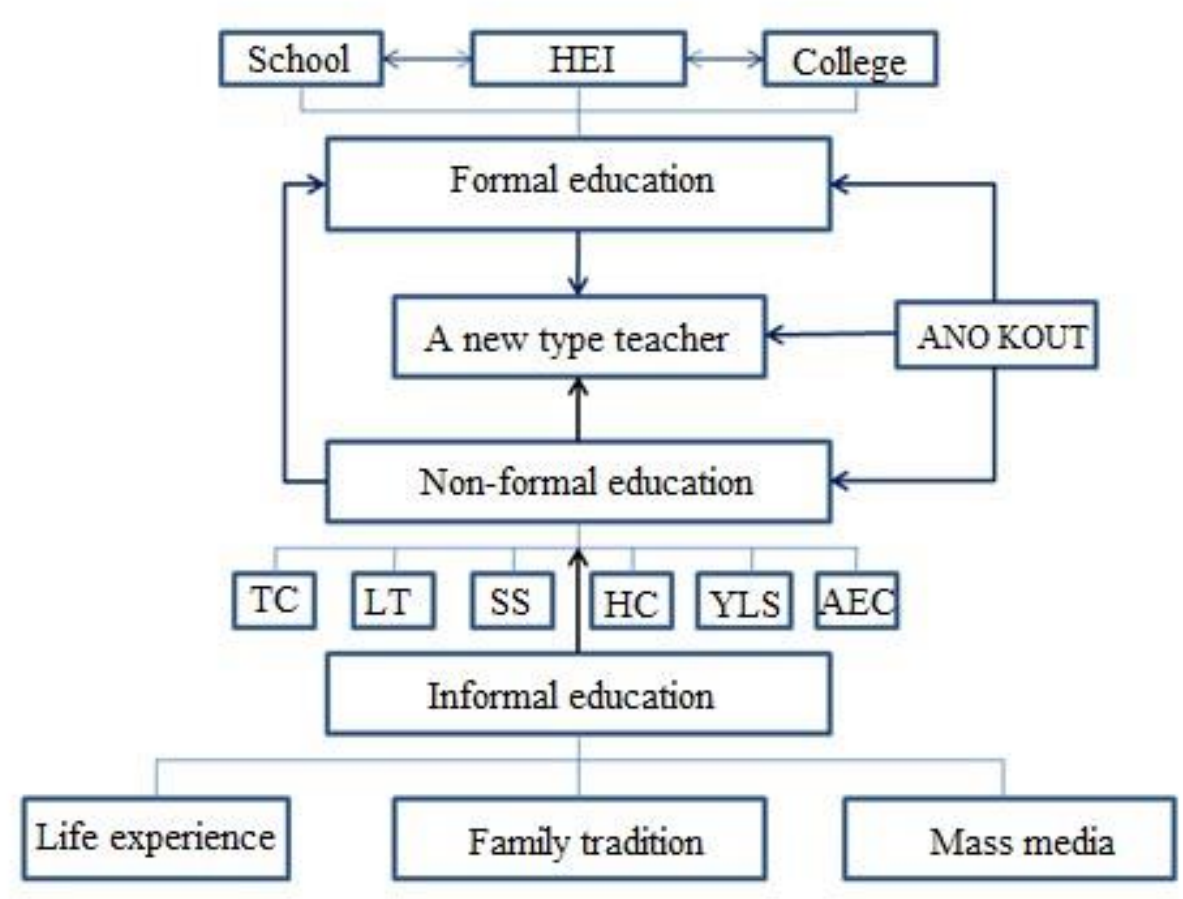

Figure 1: TC - training class, LT - talent laboratory, SS - scientific society, HC - hobby club, YLS - a young leader school, AEC - extended education courses, ANO KOUT - autonomous noncommercial organisation Kazan Open University of Talents.

Informal education is performed at every moment of human interaction with the surrounding world and is the basis for further non-formal education. It influences the materialisation of interests, needs and abilities of a person in public and personal life.

The undoubted advantage of non-formal education is its focus on equal partner relations between the teacher and the student, which allows jointly building the educational process.

The organisers of networking raise the issue of a need to create a coordination centre for the cooperation to be more effective at the local levels. In the Figure 1, the Kazan Open University of Talents (hereinafter - UT) might take over the function of such a centre.

The soft skills are formed gradually in the context of networking cooperation between different educational establishments. The authors introduce the following model of networking cooperation for a new-type teacher's soft skills formation (Figure 2).
At the first stage, a model of partnership between the school and non-formal educational establishments is created to develop basic soft skills (elementary level) (Table 1). The partnership is based on joint vocation-oriented activity, the purpose of which is to contribute to the professional self-determination of students and to form lifelong skills. The researchers believe that the paradigm of professional selfdetermination is replaced by the paradigm of general self-determination. At this point, the parents become participants of the networking cooperation as the main interested link.

This partnership should lead to the identification and vocation-oriented preparation of pedagogically gifted students. This stage of the model can be described as the integration of autonomous cooperation with the partial leadership of the school (S1), which takes responsibility for creating a teaching orientation class. The school implements an education programme that has some of the elements for gaining pedagogical experience in a teaching orientation class. In this case, the pedagogical 
experience is the basic soft skills formation: organisational skills, communication skills and self-management skills, teamwork skills, the experience of designing and implementing social and pedagogical projects, as well as an individual program of development (IPD). The forms of networking cooperation can include vocational tests, workshops, social activities, teaching projects, and others.

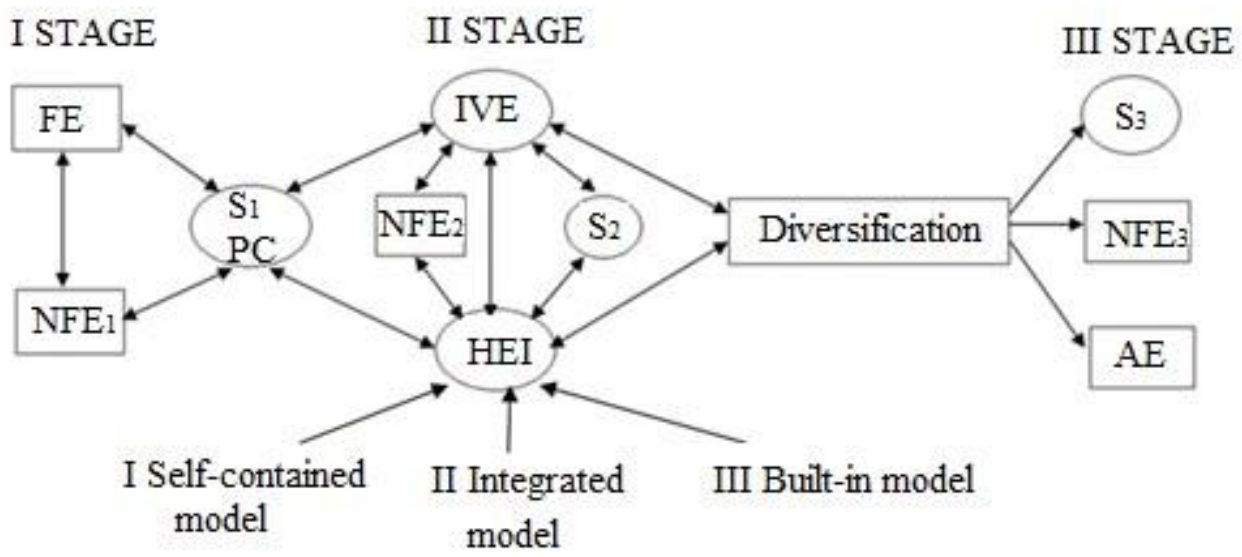

Figure 2. I stage: FE - formal education organisation (schools, grammar schools, lyceums). NFE1 - non-formal education organisation (extended education). S1 PC - school that has established a profile class (teaching orientation class). II stage: NFE2 and S2 - informal and formal education establishments (schools) as a place of pedagogical practice. IVE - intermediate vocational education establishments (pedagogical college). HEI - higher teacher education institutions. III stage: NFE3 and S3 -informal and formal education institutions (schools) as employers. AE continuing academic education as an element of diversification in teacher education (realm of pedagogical science).

At the second stage, pedagogically gifted children, who were motivated to be teachers and have entered the teachers' college (SVE secondary vocational education) are engaged into the process of forming basic soft skills of the second level. At the same time, there are enrolees, coming to educational establishments who did not pass the preliminary training (Shurygin \& Krasnova, 2017).

At the third stage, general education organisations and extended education institutions for children act as employers. The researchers introduce a model for the graduates' soft entry into the profession through a yearlong internship. At the stage end, the young teacher will gain basic professional skills. The trainee teacher works for a year under the guidance of a teacher-mentor appointed by the school and the teacher-instructor of the graduating department. Mentoring creates conditions for the young teacher to adapt to the specific features of the multi-functional professional activity of $\mathrm{s}$ teacher. $\mathrm{He} / \mathrm{she}$ gets the opportunity for joint creativity and shared responsibility, which often frightens the young teachers. This period is significant for integrating the soft formed skills into professional skills and bringing hard skills up to automatism. 


\begin{tabular}{|c|c|c|c|c|}
\hline \multirow[t]{2}{*}{ No. } & \multirow{2}{*}{$\begin{array}{l}\text { Soft Skills and } \\
\text { their Content }\end{array}$} & \multicolumn{3}{|c|}{ Stages and Levels of Soft Skills Formation } \\
\hline & & $\begin{array}{l}\text { I stage } \\
\text { The Elementary level }\end{array}$ & $\begin{array}{l}\text { Il stage } \\
\text { The Basic level }\end{array}$ & $\begin{array}{l}\text { III stage } \\
\text { The Advanced } \\
\text { level }\end{array}$ \\
\hline 1. & $\begin{array}{l}\text { Learning skills, } \\
\text { readiness and } \\
\text { self-education } \\
\text { skills }\end{array}$ & $\begin{array}{l}\text { Student has a conscientious } \\
\text { attitude to continuous education } \\
\text { as a prerequisite of successful } \\
\text { professional and social activity }\end{array}$ & $\begin{array}{l}\text { Student is able } \\
\text { to and ready to } \\
\text { direct own } \\
\text { education, } \\
\text { to design the } \\
\text { trajectory of } \\
\text { professional } \\
\text { growth and } \\
\text { development }\end{array}$ & $\begin{array}{l}\text { Student is able } \\
\text { to learn on } \\
\text { permanent } \\
\text { basis, advancing } \\
\text { in teaching, to } \\
\text { search for } \\
\text { knowledge and } \\
\text { to improve } \\
\text { thinking skills. } \\
\text { Student is able } \\
\text { to study the } \\
\text { market, to look } \\
\text { for business } \\
\text { opportunities }\end{array}$ \\
\hline 2. & $\begin{array}{l}\text { Communication } \\
\text { skills: ability to } \\
\text { gain through } \\
\text { communication, } \\
\text { ability to } \\
\text { interact with } \\
\text { people }\end{array}$ & $\begin{array}{l}\text { Student possesses skills of } \\
\text { respectful and benevolent } \\
\text { attitude to another person, } \\
\text { his/her opinion, worldview, } \\
\text { culture ... the ability to } \\
\text { communicate with other people } \\
\text { and achieve } \\
\text { understanding mutual }\end{array}$ & $\begin{array}{l}\text { Student is ready } \\
\text { to interact with } \\
\text { other learning } \\
\text { participants. } \\
\text { Student is able } \\
\text { to express ideas } \\
\text { in oral and } \\
\text { written forms } \\
\text { clearly, } \\
\text { efficiently and } \\
\text { with } \\
\text { confidence. } \\
\text { Student } \\
\text { possesses active } \\
\text { listening and } \\
\text { responding } \\
\text { skills. Student is } \\
\text { able to present } \\
\text { him/herself } \\
\text { confidently }\end{array}$ & $\begin{array}{l}\text { Student is able } \\
\text { to discuss and } \\
\text { develop a } \\
\text { common } \\
\text { opinion, to } \\
\text { communicate } \\
\text { with } \\
\text { representatives } \\
\text { of a different } \\
\text { culture. } \\
\text { Student is able } \\
\text { to improve own } \\
\text { communication } \\
\text { skills }\end{array}$ \\
\hline 3. & $\begin{array}{l}\text { Social } \\
\text { intelligence: } \\
\text { team work } \\
\text { skills, ability to } \\
\text { perform various } \\
\text { social roles, } \\
\text { initiatives and } \\
\text { leadership }\end{array}$ & $\begin{array}{l}\text { Student possesses skills of } \\
\text { cooperation with peers, young } \\
\text { children and adults. Student is } \\
\text { able to take into account the } \\
\text { opinions of other participants and } \\
\text { to defend own point of view }\end{array}$ & $\begin{array}{l}\text { Student is able } \\
\text { to work in a } \\
\text { team, to } \\
\text { perceive social, } \\
\text { cultural and } \\
\text { personal } \\
\text { differences } \\
\text { tolerantly. } \\
\text { Student is able } \\
\text { to understand }\end{array}$ & $\begin{array}{l}\text { Student is able } \\
\text { to plan and } \\
\text { coordinate } \\
\text { group work and } \\
\text { to be } \\
\text { responsible for } \\
\text { the group } \\
\text { decision }\end{array}$ \\
\hline
\end{tabular}




\begin{tabular}{|c|c|c|c|c|}
\hline & & & $\begin{array}{l}\text { the situation } \\
\text { and } \\
\text { alternatively } \\
\text { choose the role } \\
\text { of a leader or a } \\
\text { follower }\end{array}$ & \\
\hline 4. & $\begin{array}{l}\text { Management } \\
\text { skills: idea } \\
\text { promotion from } \\
\text { thought design } \\
\text { to a meaningful } \\
\text { guaranteed } \\
\text { result, ability to } \\
\text { manage people }\end{array}$ & $\begin{array}{l}\text { Student is able to correlate own } \\
\text { actions with the targets, monitor } \\
\text { own activities while achieving the } \\
\text { outcome. Student is able to } \\
\text { determine the action methods for } \\
\text { certain conditions and } \\
\text { requirements, adjust the actions } \\
\text { in accordance with a changing } \\
\text { situation, to plan independently } \\
\text { the ways of achieving the targets }\end{array}$ & $\begin{array}{l}\text { Student is able } \\
\text { to support } \\
\text { children; } \\
\text { organise their } \\
\text { cooperation, } \\
\text { support activity } \\
\text { and initiatives, } \\
\text { independence, } \\
\text { develop their } \\
\text { creative } \\
\text { abilities, } \\
\text { manage } \\
\text { educational and } \\
\text { research } \\
\text { activities and } \\
\text { design } \\
\text { individual } \\
\text { learning } \\
\text { trajectories for } \\
\text { children }\end{array}$ & $\begin{array}{l}\text { Student is able } \\
\text { to control team } \\
\text { members, } \\
\text { manage the } \\
\text { process in order } \\
\text { to improve the } \\
\text { organisation } \\
\text { effectiveness. } \\
\text { Student is able } \\
\text { to identify new } \\
\text { ideas, promote } \\
\text { their } \\
\text { advancement, } \\
\text { create } \\
\text { conditions for } \\
\text { effective activity } \\
\text { and to be a } \\
\text { mentor for } \\
\text { children }\end{array}$ \\
\hline 5. & $\begin{array}{l}\text { Skills of } \\
\text { psychophysical } \\
\text { self- } \\
\text { organisation, } \\
\text { ability to cope } \\
\text { with problems, } \\
\text { emotional } \\
\text { intelligence }\end{array}$ & $\begin{array}{l}\text { Student possesses self- } \\
\text { assessment skills. Student is able } \\
\text { to apply speech tools } \\
\text { meaningfully in accordance with } \\
\text { communication goals to express } \\
\text { own feelings, thoughts and needs. } \\
\text { Student is aware of own and other } \\
\text { people's emotions. Student is able } \\
\text { to empathise }\end{array}$ & $\begin{array}{l}\text { Student is able } \\
\text { to and ready for } \\
\text { self- } \\
\text { organisation. } \\
\text { Student is able } \\
\text { to overcome } \\
\text { stress, to } \\
\text { manage one's } \\
\text { time. Student is } \\
\text { ready to } \\
\text { maintain the } \\
\text { fitness level, } \\
\text { contributing to } \\
\text { full-fledged } \\
\text { activity and } \\
\text { openness to } \\
\text { criticism }\end{array}$ & $\begin{array}{l}\text { Student } \\
\text { possesses self- } \\
\text { employment } \\
\text { skills. Student is } \\
\text { able to create a } \\
\text { comfortable } \\
\text { emotional } \\
\text { atmosphere and } \\
\text { to resolve } \\
\text { conflicts } \\
\text { effectively }\end{array}$ \\
\hline 6. & $\begin{array}{l}\text { Thinking skills: } \\
\text { ability to think } \\
\text { critically to } \\
\text { solve complex } \\
\text { problems and } \\
\text { make decisions, }\end{array}$ & $\begin{array}{l}\text { Student possesses skills of } \\
\text { information collection from } \\
\text { various sources. Student is able to } \\
\text { assess critically and choose the } \\
\text { most effective way of solving } \\
\text { problems, }\end{array}$ & $\begin{array}{l}\text { Student is able } \\
\text { to identify and } \\
\text { analyse } \\
\text { problems in a } \\
\text { difficult } \\
\text { situation and to }\end{array}$ & $\begin{array}{l}\text { Student is able } \\
\text { to predict the } \\
\text { events and } \\
\text { make } \\
\text { appropriate } \\
\text { decisions. }\end{array}$ \\
\hline
\end{tabular}




\begin{tabular}{|c|c|c|c|c|}
\hline & $\begin{array}{l}\text { find problem- } \\
\text { oriented } \\
\text { solutions (not in } \\
\text { general, but } \\
\text { solve a specific } \\
\text { problem), } \\
\text { cognitive } \\
\text { flexibility }\end{array}$ & $\begin{array}{l}\text { make decisions in educational and } \\
\text { cognitive activities }\end{array}$ & $\begin{array}{l}\text { give a valid } \\
\text { estimate. The } \\
\text { opportunity to } \\
\text { expand and } \\
\text { improve } \\
\text { thinking skills, } \\
\text { such as } \\
\text { explanation, } \\
\text { analysis and } \\
\text { evaluation of } \\
\text { discussion. } \\
\text { Student is able } \\
\text { to generate } \\
\text { ideas and look } \\
\text { for alternative } \\
\text { solutions. } \\
\text { Student is able } \\
\text { to solve } \\
\text { problems of } \\
\text { upbringing, } \\
\text { spiritual and } \\
\text { moral } \\
\text { development of } \\
\text { children } \\
\text { through } \\
\text { learning and } \\
\text { extracurricular } \\
\text { activities }\end{array}$ & $\begin{array}{l}\text { Student is able } \\
\text { to draw } \\
\text { conclusions } \\
\text { based on valid } \\
\text { evidence. } \\
\text { Student is able } \\
\text { to adapt } \\
\text { consciously to a } \\
\text { diverse work } \\
\text { environment. }\end{array}$ \\
\hline 7. & $\begin{array}{l}\text { Skills of } \\
\text { ecologically } \\
\text { conscious } \\
\text { behaviour }\end{array}$ & 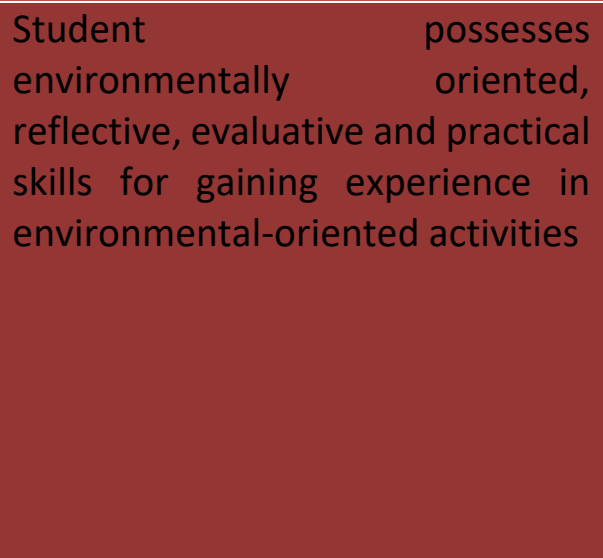 & $\begin{array}{l}\text { Student is able } \\
\text { to apply the } \\
\text { basics of } \\
\text { philosophical } \\
\text { and socio- } \\
\text { humanitarian } \\
\text { knowledge to } \\
\text { shape } \\
\text { responsible } \\
\text { attitude to } \\
\text { nature }\end{array}$ & $\begin{array}{l}\text { Student is able } \\
\text { to be in ethical } \\
\text { relationships, to } \\
\text { be responsible } \\
\text { for own } \\
\text { ecological } \\
\text { footprint }\end{array}$ \\
\hline
\end{tabular}

Sources:

\section{Discussion}

The practice of advanced teacher training through autonomous networking cooperation is widely spread as a form of cooperation with various institutions and publishing houses under partial leadership of the international organisation (International House Frankfurt acàdemia Suarez, 2018). Such model implies the union of equal partners to accompany the programme of advanced training, where each participant is responsible for a certain type of activity. Cooperation participants are included in the coordination council. 
At the stage of the school-university partnership, networking cooperation is carried out through a strong network, when the higher educational establishment is the central organisation coordinating the cooperation between the schools and extended educational establishments. This central organisation often acts in its own interests (Devlet-Geldy, 2015). In terms of network management, this model is not effective because it is built on the principles of a vertical hierarchy, not partnership interaction. The expected outcome requires strengthening the practice-oriented competency-based approach to teacher training. At this point, distributed network model will be more appropriate. The identically distributed network model shall be applied at the time of handling the instrumental distributed network, based on the resource exchange system aimed at solving problems. Another option for cooperation is aimed at achieving a common outcome, in this case, at preparing a teacher possessing the basic soft skills (Stage II, Figure 2).

The chain model is a linear hierarchical structure of interaction when each partner strictly takes part in the achievement of a common goal. In this case, the first chain link organises the whole process.

Although the sequence of stages seems to be a linear one, the introduced model is a solid network. In fact, only a more complicated process of soft skills formation is liner in sequence - each subsequent level of soft skills is achieved from the previous one.

The education programme model is often applied to solve the problem of practiceoriented learning. In this case, institutions of secondary vocational education and the employer jointly design and implement education programme. The latter is in order to learn the conditions that increase teaching and learning effectiveness and to build their models to improve education quality (Thessin et al., 2017).

The variety of described models of networking cooperation is not completed or strictly obligatory; this is just the basis for further modelling of relationships. The new system requirements in solving relevant problems and achieving the required outcomes can lead to new options. The significance of networking cooperation lies not behind the model, but behind the process of achieving a high-quality outcome with it that would correspond to the needs of society.

\section{Conclusion}

Thus, teachers' soft skills formation requires his/her engagement in formal and non-formal communication with children, which is impossible without coordinated actions and mutually adapted programmes of formal and non-formal education. The teacher education standards should be extended by creating an educational environment in the form of a network, where the student is not an education programme consumer, but a co-author of own learning trajectory corresponding to personal characteristics (interests, inclinations, needs).

The teacher must get a time shot to solve the problems, set in the modern educational system, effectively, namely, to possess socially important skills or soft skills. These are the abilities to create partnership, identify the interests and needs of a modern child in order to adapt the teaching and learning process to these characteristics. Other abilities include abilities to combine education and life not opposing them, learn and teach other children how to live in the changing environment.

The school-university partnership prototype analysis revealed a number of shortcomings in the research organisation. For example, the selection of tools for assessing the soft skills formation dynamics as a model to identify gaps between the personal competencies and the expected ones. It is also necessary to compare the mono-models of soft skills formation with the competences shaped through networking cooperation.

The researchers cannot bring forward the results of networking cooperation yet, as the model shall be rebuilt over time. However, preparing a teacher of a new type allowed the reseachers to witness that several conditions must be met to foster the teaching behaviour. 
Thus, organisations have to provide early-career guidance for a potential teacher, create an environment, where all the elements of the educational system (university, school, college, extended education establishments) will interact with one another. They also have to engage the student into the non-formal activity, to change the teacher education standards in order to make them more flexible by increasing the share of practical activity, providing a choice of specialisations and a possibility to design a personal learning trajectory under the guidance of a mentor.

\section{References}

Al Jarrah, H. Y. (2019). Six thinking hats: An analysis of the skill level of Jordanian vocational education teachers and the extent of skill application. Space and Culture, India, 7(1), 170-185. doi: 10.20896/saci.v7i1.470

APEC Education Cooperation Strategies (2016). Institute of APEC Collaborative Education Ministry of Education. Republic of Korea. Retrieved from http://apec-center.ru/wpcontent/uploads/2016/10/APEC-

Education-Cooperation-

Strategies_2016.7.18_v.3.8.pdf

Claxton, G., Costa, A., \& Kallick, B. (2016). Hard thinking about soft skills. Educational Leadership, 73(6), 60-64.

Code of Good Practice in the Provision of Transnational Services (2002). Strasbourg. Retrieved from

http://www.coe.int/t/dg4/highereducatio $\mathrm{n} /$ recognition/code\%20of\%20good\%20pr acticeEN.asp

Devlet-Geldy, G.K. (2015). Social partnership of school and University. Humanities Bulletin, 6 .

Di Russo, S. (2016). Understanding the behaviour of design thinking in complex environments. Unpublished PhD thesis. Melbourne: Swinburne University.

Freeman, D. (2015). The problem of the influence of the electronic environment on intellectual development and interpersonal relations of gifted and talented children. Psychological Science and Education, 20(1), 102-109.

Galazhinsky, E. (2017). What is not taught at universities? Vedomosti. Retrieved from https://www.vedomosti.ru/opinion/articl es/2017/08/03/727760-ne-uchat-vuniversitetah

Gerstein, J. (2017). Moving from Education 1.0 through Education 2.0 Towards Education 3.0. Retrieved from https://usergeneratededucation.wordpre ss.com/2014/12/01/experiences-in-selfdetermined-learning-moving-fromeducation-1-0-through-education-2-0towards-education-3-0/

International House Frankfurt acàdemia Suarez (2018). Retrieved from http://teachertraininggermany.de/teacher-trainingenglish/seminare-cpd

Jonas, D.L., Garland, M., \& Yamaguchi, R. (2014). Following Virginia's Career and Technical Education completers out of high school and into college. A study of high school graduates' college enrollment, persistence, and completion (pp. 50).

Retrieved from http://vlds.virginia.gov/media/1016/ctep ostsecondary.pdf

Joseph, D.L., \& Newman, D.A. (2010). Emotional intelligence: An integrative meta-analysis and cascading model. Journal of Applied Psychology, 95(1).

Kamyshanchenko, E.N., \& Stepanenko, S.N. (2014). Factors of innovative development of subjects of the international market of educational services in the system of higher education. Modern problems of science and education, 6.

Kang, S., Day, J.D., \& Meara, N. M. (2006). Soziale und emotionale Intelligenz: Gemeinsamkeiten und Unterschiede (pp. 101-115). Gottingen, Germany: Hogrefee.

Kasprzhak, A.G., \& Kalashnikov, S. P. (2014). Priority of educational results as a tool of modernisation of teacher training 
programs. Psychological science and education, 19(3), 87-104.

Khabiri, M. M., \& Bahabad, M. J. A. (2019). Teaching and learning of practical skills: Learning from the pavement laboratory course. Journal of Technical Education and Training, 11(2).

Maharoff, M., \& Hassan, A. (2015). Lecturers' understanding and teaching practices in embedding soft skills into compulsory courses. Proceedings of INTCESS15-2nd International Conference on Education and Social Sciences. Turkey: Istanbul.

Malik, A.B. (2010). Public-private partnerships in Education Lessons learned from the Punjab Education Foundation (pp. 29). Mandaluyong City, Philippines: Asian Development Bank.

Mikhailova, E.S. (2007). Social intelligence: Concepts, models, diagnostics. SPb., SPbU. Retrieved from http://psytests.org/iq/guilford/guilford.ht $\mathrm{ml}$

Pachauri, D., \& Yadav, A. (2014). Importance of soft skills in teacher education Programme. Int. J. Educat. Res. Technol., 5(1), 22-25.

Popova, I.N. (2016). Network interaction as a resource for the development of general and additional education. Internet-journal "The World of Science", 4(6).

Rouse, M. (2008). Developing inclusive practice: A role for teachers and teacher education. Retrieved from https://www.researchgate.net/publicatio
n/268341709_Developing_Inclusive_Pract ice_A_Role_for_Teachers_and_Teacher_E ducation

Shurygin, V.Y., \& Krasnova, L.A. (2017). The peculiarities of pedagogical projects implementation for identification and development of giftedness in children. Astra Salvensis, 1, 47-54.

Shurygin, V.Y., \& Sabirova, F.M. (2017). Implementation in teaching physics by means of LMS Moodle. Espacios, 38(40), 39.

Thessin, R.A., Scully-Russ, E., \& Lieberman, D.S. (2017). Critical success factors in a high school healthcare education program. Journal of Career and Technical Education, 32(1).

Vincent-Lankran, S. (2010). Cross-border higher education: Trends and development prospects. Bulletin of International Organisations, 3(29).

Zhukova, T., Bogoslovskiy, V., Dobudko, T., Sevenyuk, S., \& Vershinina, L. (2019). Multicultural teaching in regions (within sustainability conception in education). Space and Culture, India, 7(1), 274-284. doi: $10.20896 /$ saci.v7i1.437

\section{Acknowledgements}

The authors express their gratitude to the administration of Kazan Federal University for support in the publication of the article.

\section{Conflict of interest statement}

Authors declare that they have no conflict of interests 